OAK RIDGE
NATIONAL LABORATORY

MANAGED BY UT-BATTELLE

FOR THE DEPARTMENT OF ENERGY

\section{Strength Evaluation of PyC for TRISO Particles: Development of Equibiaxial Flexural Test}

\author{
Y. Katoh, S. Kondo, L.L. Snead, and \\ J.D. Hunn
}

Sept 2008
This report was prepared as an account of work sponsored by an agency of the United States Government. Neither the United States Government nor any agency thereof, or any of their employees, makes any warranty, expressed or implied, or assumes any legal liability or responsibility for any third party's use, or the results of such use, of any information, apparatus, product or process disclosed in this report, or represents that its use by such third party would not infringe privately owned rights. 


\section{DOCUMENT AVAILABILITY}

Reports produced after January 1, 1996, are generally available free via the U.S. Department of Energy (DOE) Information Bridge.

Web site http://www.osti.gov/bridge

Reports produced before January 1, 1996, may be purchased by members of the public from the following source.

National Technical Information Service

5285 Port Royal Road

Springfield, VA 22161

Telephone 703-605-6000 (1-800-553-6847)

TDD 703-487-4639

Fax 703-605-6900

E-mail info@ntis.fedworld.gov

Web site http://www.ntis.gov/support/ordernowabout.htm

Reports are available to DOE employees, DOE contractors, Energy Technology Data Exchange (ETDE) representatives, and International Nuclear Information System (INIS)

representatives from the following source.

Office of Scientific and Technical Information

P.O. Box 62

Oak Ridge, TN 37831

Telephone 865-576-8401

Fax 865-576-5728

E-mail reports@adonis.osti.gov

Web site http://www.osti.gov/contact.html

This report was prepared as an account of work sponsored by an agency of the United States Government. Neither the United States Government nor any agency thereof, nor any of their employees, makes any warranty, express or implied, or assumes any legal liability or responsibility for the accuracy, completeness, or usefulness of any information, apparatus, product, or process disclosed, or represents that its use would not infringe privately owned rights. Reference herein to any specific commercial product, process, or service by trade name, trademark, manufacturer, or otherwise, does not necessarily constitute or imply its endorsement, recommendation, or favoring by the United States Government or any agency thereof. The views and opinions of authors expressed herein do not necessarily state or reflect those of the United States Government or any agency thereof. 
ORNL/TM-2008/164

\title{
Strength Evaluation of PyC for TRISO Particles: Development of Equibiaxial Flexural Test
}

\author{
Y. Katoh, S. Kondo, L.L. Snead, J.D. Hunn
}

\author{
Date Published: \\ September 22, 2008 \\ Prepared for \\ Office of Nuclear Energy Science and Technology \\ Prepared by \\ OAK RIDGE NATIONAL LABORATORY \\ Oak Ridge, Tennessee 37831 \\ managed by \\ UT-BATTELLE, LLC \\ for the \\ U.S. DEPARTMENT OF ENERGY \\ under contract DE-AC05-00OR22725
}




\section{Summary}

For the purpose of evaluating fracture strength of IPyC for TRISO particles, a disc equibiaxial flexural test technique was developed and IPyC-relevant specimens fabricated in a test-run of fluidized-bed chemical vapor deposition were evaluated. It was demonstrated that the test technique developed is effective to determine the apparent fracture strength of thin specimen of PyC. Moreover, true local strength was estimated from the acquired apparent strength values based on the result from finite element analysis. The estimated true local strength values appeared reasonable for flexural strength of dense PyC, and can be used for determination of fracture stresses which depend on the effective surface. The influence of geometrical features introduced to the specimens due to the specific preparation procedures appeared insignificant.

The following issues need to be addressed in future work.

1) An explicit and rigorous procedure for determining true local strength value from the experimentally obtained apparent strength value needs to be established.

2) Origin of the observed dependence of estimated true strength on specimen thickness has to be clarified. This includes the influence of the presence of buffer PyC layer.

3) The test method including both the data acquisition and the analytical procedure needs to be validated. 


\section{Objectives}

The failure criteria of the IPyC layer are among the critical parameters which decide the performance of TRISO fuel particles. However, a sufficiently reliable and relevant method of strength evaluation for IPyC has not been available to date. Considering that the anticipated primary failure mode of IPyC is equibiaxial tension (initiating from the inner surface) due to internal pressure developed by accumulation of gaseous fission products, equibiaxial flexural testing is one of the best available techniques which are capable of 1) testing a small specimen that is produced in a fluidized bed, 2) applying equibiaxial tensile loading onto at least one side of the specimen, 3) testing in a simple and robust manner, making post-irradiation evaluation fairly easy, and 4) producing statistically significant data from a small neutron irradiation experiment. The objective of this work is to develop an equibiaxial disc flexural test for strength determination of PyC material relevant with IPyC in TRISO fuel particles. The present document reports the initial result of the strength tests performed using PyC samples produced by fluidized-bed chemical vapor deposition (CVD) at Oak Ridge National Laboratory.

\section{Experimental Procedure}

The equibiaxial flexural test in a "ring-on-ring" configuration, where a disc specimen of ceramic is placed on a support ring and loaded with a smaller diameter coaxial loading ring, was adopted as a method of strength evaluation. This test method is often utilized for equibiaxial strength of brittle ceramics and the test procedure is standardized in ASTM C1499-05. [1]

A typical disc equibiaxial flexural test utilizes ceramic specimens of diameter of the order of one inch. However, because the evaluation of PyC samples requires testing using much smaller dimensions, a dedicated fixture was designed and fabricated. The section view of the test setup is shown in Fig. 1 and in a set of photographs in Fig. 2. The physical parameters of the test configuration and the condition of testing are summarized in Table. 1.

Specimens used were prepared through the fluidized-bed CVD process at Oak Ridge National Laboratory, run number AGR-500ZRO2-Disk11. Dimensions of the disc specimens were $\sim 6.3 \mathrm{~mm}$ (diameter) $\mathrm{x} \sim 0.12 \mathrm{~m}$ (thickness). This thickness includes a buffer PyC layer of $\sim 0.025 \mathrm{~mm}$. Details of the fabrication procedure and the specimen characterization (microstructures, etc.) will be reported in a separate document [2]. Equibiaxial flexural testing was performed so that the face with the buffer PyC layer on it was loaded in tension.

Due to the difference in procedure of the disc specimen preparation, some of the discs were received with slight "cupping," or with a slight partial-cylindrical wall perpendicular to the disc face attached to the circumference, whereas the other discs were with geometrically 
non-smooth perimeters. These features in specimen geometry are shown in photographs in Appendix A.

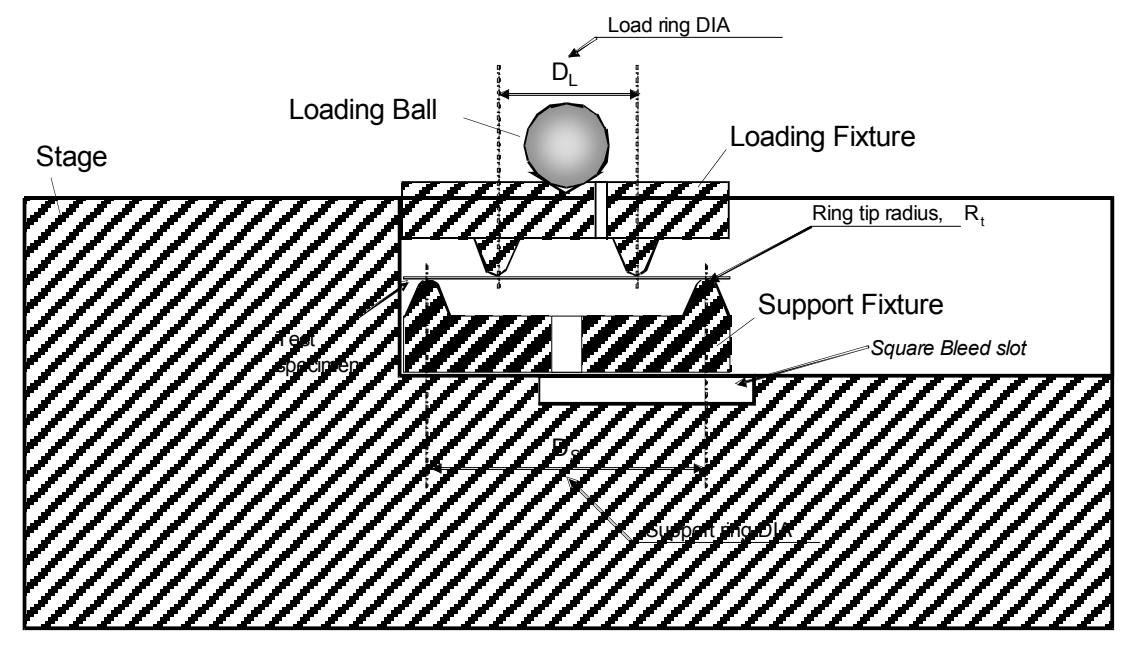

Fig. 1. Section view of the equibiaxial flexural test configuration.

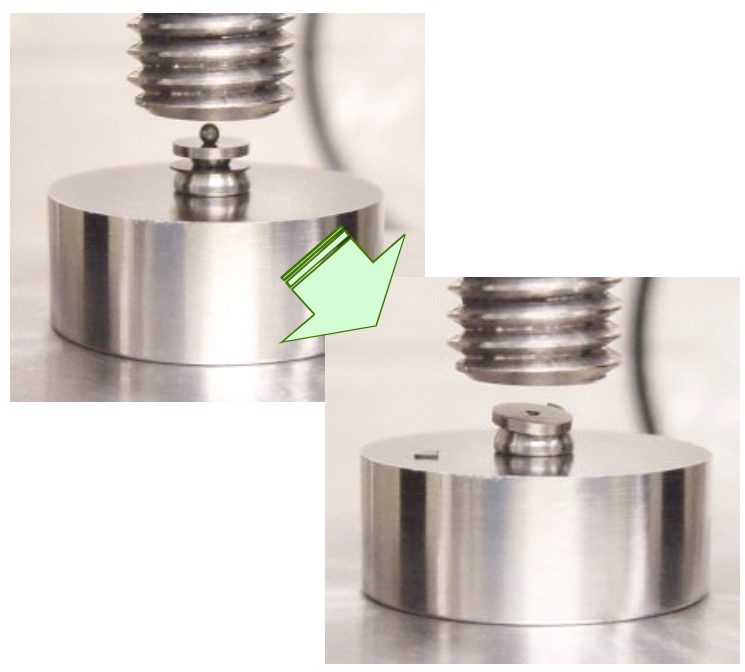

Fig. 2. Photographs of test specimen and fixture before (top-left) and after (bottom-right) testing. 
Table 1. Physical parameters and condition of the test.

\begin{tabular}{ccc}
\hline Parameter & Symbol & Value \\
\hline Support ring diameter & $D_{S}$ & $5 \mathrm{~mm}$ \\
Loading ring diameter & $D_{L}$ & $2.5 \mathrm{~mm}$ \\
Ring tip radii & $R_{S}, R_{L}$ & $0.3 \mathrm{~mm}$ \\
\hline Test temperature & $T$ & Ambient \\
Crosshead displacement rate & $\dot{\delta}$ & $0.1 \mathrm{~mm} / \mathrm{s}$ \\
\hline
\end{tabular}

\section{Results and Discussion}

Results of the equibiaxial flexural tests are summarized in Table 2. The apparent flexural strength was determined by the following equation per ASTM Standard C1499-05,

$$
\sigma_{f}=\frac{3 F}{2 \pi h^{2}}\left[(1-v) \frac{D_{S}{ }^{2}-D_{L}^{2}}{2 D^{2}}+(1+v) \ln \frac{D_{S}}{D_{L}}\right]
$$

where $F=$ fracture load, $h=$ specimen thickness, $v=$ Poisson's ratio, and $D=$ specimen diameter. This equation is valid only when specimen deflection height remains negligible with regard to the specimen thickness during testing.

Table 2. List of measured information

\begin{tabular}{ccccccccc}
\hline $\begin{array}{c}\text { Sample } \\
\text { ID }\end{array}$ & Cupping & $\begin{array}{c}\text { Thickness, Thickness, } \\
\text { total } \\
{[\mathrm{mm}]}\end{array}$ & $\begin{array}{c}\text { PyC }^{1} \\
{[\mathrm{~mm}]}\end{array}$ & $\begin{array}{c}\text { Fracture } \\
\text { Load } \\
{[\mathrm{N}]}\end{array}$ & $\begin{array}{c}\text { Apparent } \\
\text { Strength }^{2} \\
{[\mathrm{MPa}]}\end{array}$ & $\begin{array}{c}\text { Estimated } \\
\text { Deflection } \\
{[\mathrm{mm}]}\end{array}$ & $\begin{array}{c}\text { Correction } \\
\text { Factor }^{3}\end{array}$ & $\begin{array}{c}\text { Estimated } \\
\text { True Local } \\
\text { Strength }^{4} \\
{[\mathrm{MPa}]}\end{array}$ \\
\hline PyC080721_01 & Yes & 0.127 & 0.102 & 8.97 & 254 & 0.16 & 0.31 & 123 \\
PyC080721_02 & No & 0.135 & 0.110 & 10.82 & 279 & 0.17 & 0.28 & 115 \\
PyC080721_03 & Yes & 0.125 & 0.100 & 11.81 & 352 & 0.17 & 0.26 & 141 \\
PyC080721_04 & Yes & 0.109 & 0.084 & 14.65 & 581 & 0.19 & 0.23 & 219 \\
PyC080721_05 & Yes & 0.127 & 0.102 & 16.10 & 465 & 0.20 & 0.22 & 156 \\
PyC080721_06 & No & 0.112 & 0.087 & 19.55 & 734 & 0.21 & 0.19 & 226 \\
PyC080721_07 & No & 0.111 & 0.086 & 15.18 & 580 & 0.19 & 0.22 & 208 \\
\hline Average & & 0.121 & 0.096 & & 464 & & & 170 \\
Std. Dev. & & 0.010 & 0.010 & & 178 & & & 47 \\
\hline
\end{tabular}

1) It was assumed that the buffer PyC layer is of thickness $0.025 \mathrm{~mm}$ in all samples.

2) Apparent strength was determined following ASTM C1499-05 assuming that the buffer PyC layer possesses the same strength as PyC.

3) Correction factor is a rough estimate of the ratio of true stress to the apparent stress. As the preliminary treatment, the correction factor was determined as a function of deflection.

4) True local strength was estimated based on the correction factor and the assumption that the buffer PyC layer is NOT contributing to strength. 
The mean value of apparent equibiaxial flexural stress for fracture of seven samples tested was $454 \mathrm{MPa}$. However, the measured strength values widely varied in a range 254-734 $\mathrm{MPa}$ and exhibited negative dependency on the sample thickness as clearly shown in Fig. 3. Also considering the fact that the estimated maximum heights of specimen deflection shown in Table 2 are very significant as compared to the specimen thickness, meaning that significant stress concentration around the loaded location has occurred, the results obtained indicate that Eq. (1) can not be simply applied. The crack patterns, shown in Appendix A indicate cracking along the circle corresponding to the location loaded by the loading ring, verifying the stress concentration at the loading ring.

The anticipated influence of mechanical constraint by cupping appeared less significant as compared to the thickness effect. For the highest strength case, crosshead displacement was $\sim 0.2 \mathrm{~mm}$ with the maximum load of $\sim 20 \mathrm{~N}$, which is consistent with the finite element calculation for the $25 \mathrm{GPa}$ Young's modulus case (typical for dense PyC) as shown in Fig. 4. Using results from the finite element analysis, true fracture strength values of the present PyC samples were estimated and shown in Table 2.

The estimated true local strength values are within a typical range of the flexural strength of dense PyC. However, as seen in Fig. 4, the estimated true strength still exhibits a negative correlation with the specimen thickness. This may be due to contribution from the buffer PyC layer to the strength, which was ignored in the estimation of true strength. The reason for this trend needs to be clarified in future work. More importantly, a standard procedure for determination of true local strength needs to be established based on the finite element analysis. Fracture strength of the PyC layer, which should be used in models for fuel performance evaluation, can be determined using values of the true local strength, the effective loading area, Weibull parameters (both scale and shape parameters), and the loaded surface area in actual application. 


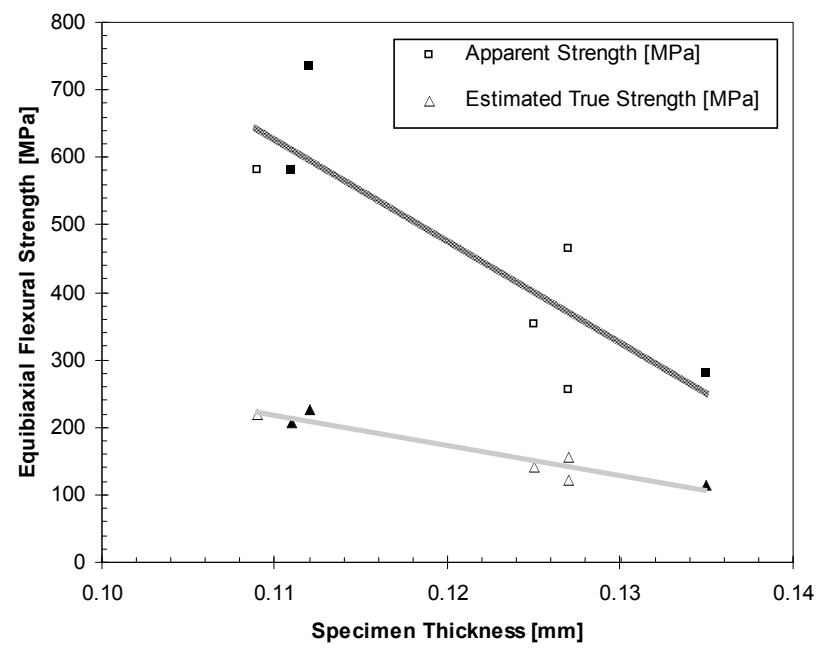

Fig. 3 Specimen thickness dependence of the apparent strength of PyC as determined by equibiaxial flexural test. Closed symbols indicate data points from specimens without "cupping." Note that the apparent strength values are significantly higher than the estimated true strength values (see text).

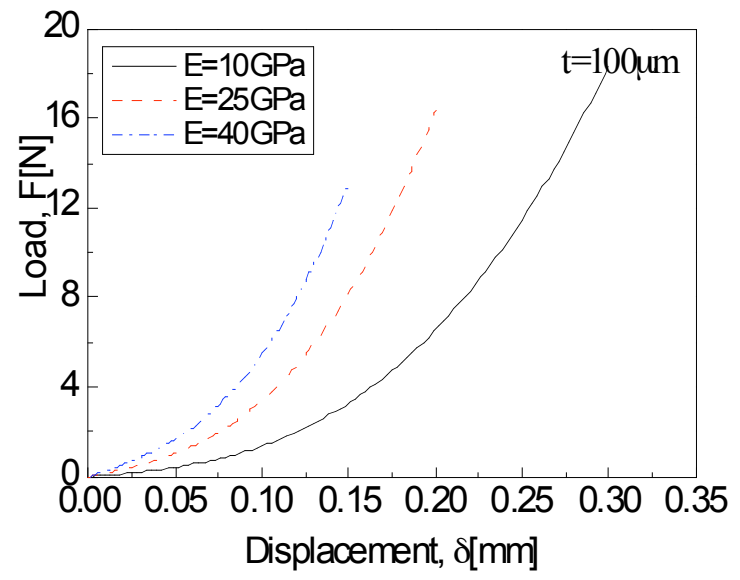

Fig. 4 Load-displacement curves for PyC disc samples ( $0.1 \mathrm{~mm}$ thickness $)$ as predicted by finite element analysis. Typical Young's modulus (E) is $\sim 25 \mathrm{GPa}$ for dense PyC.

It is noteworthy that the estimated local fracture stress values are not significantly different between specimens with "cupping" and specimens with uneven perimeter but without "cupping." However, specimens without "cupping" are preferred because it is anticipated that the stress state in specimens will be more significantly disturbed by the "cupping" than by the uneven perimeter. 
References

[1] ASTM Standard C1499-05, "Standard Test Method for Monotonic Equibiaxial Flexural Strength of Advanced Ceramics at Ambient Temperature," ASTM International, West Conshohocken, PA.

[2] J. H. Miller, K. M. Cooley, and B. C. Jolly, "Coating R\&D in Support of PyC Strength Measurement: FY08 Progress Report," Oak Ridge National Laboratory, September 2008, Oak Ridge, TN. 


\section{Appendix A}

Optical images of individual specimens before/after testing and load-displacement relationship obtained during testing. 
PyC080721_01

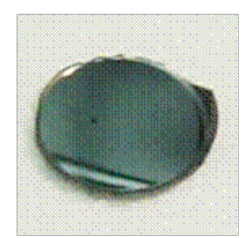

\begin{tabular}{|l|l|}
\hline Thickness [mm] & 0.1273 \\
\hline Peak Load [N] & 8.97 \\
\hline Flexural Stress [MPa] & 254.2 \\
\hline Likely Crack Origin & under loading ring \\
\hline
\end{tabular}
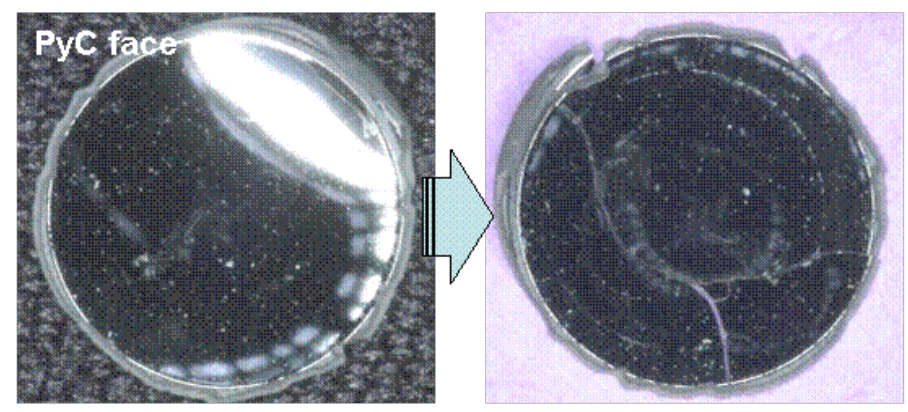

\section{Remarks: strength curve drop slight misalignment}
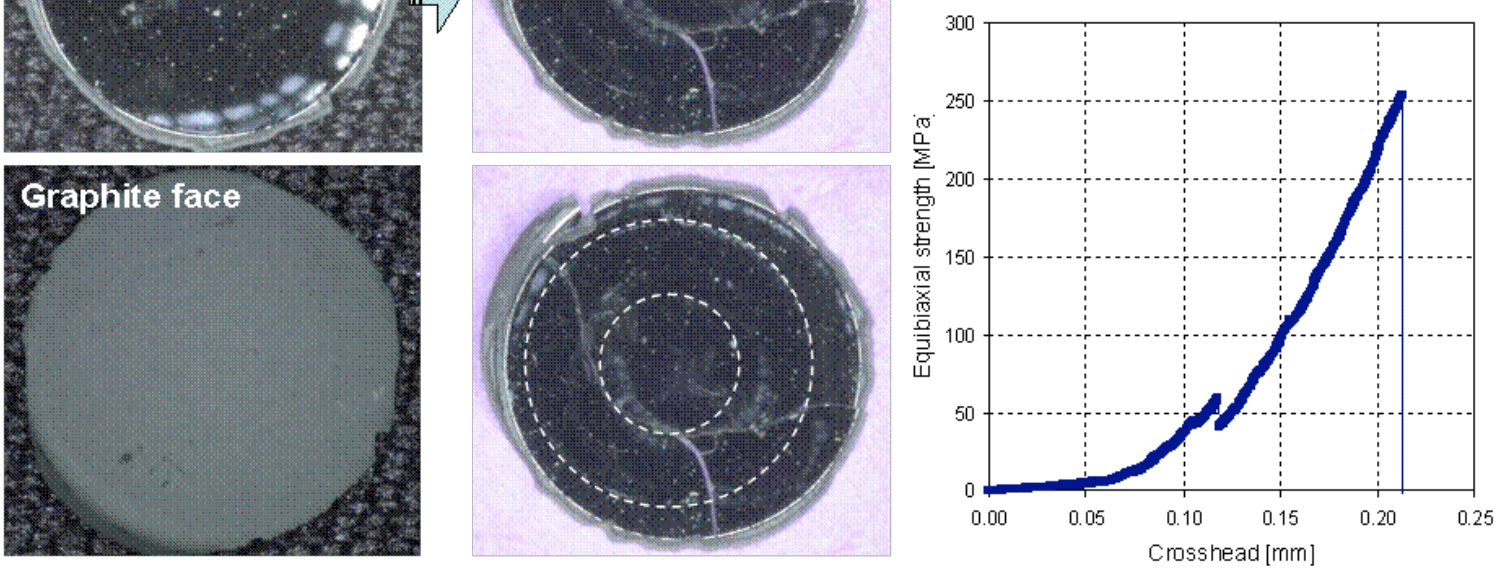
PyC080721_02

\begin{tabular}{|l|l|}
\hline Thickness [mm] & 0.1347 \\
\hline Peak Load [N] & 10.82 \\
\hline Flexural Stress [MPa] & 279.3 \\
\hline Likely Crack Origin & under loading ring \\
\hline
\end{tabular}
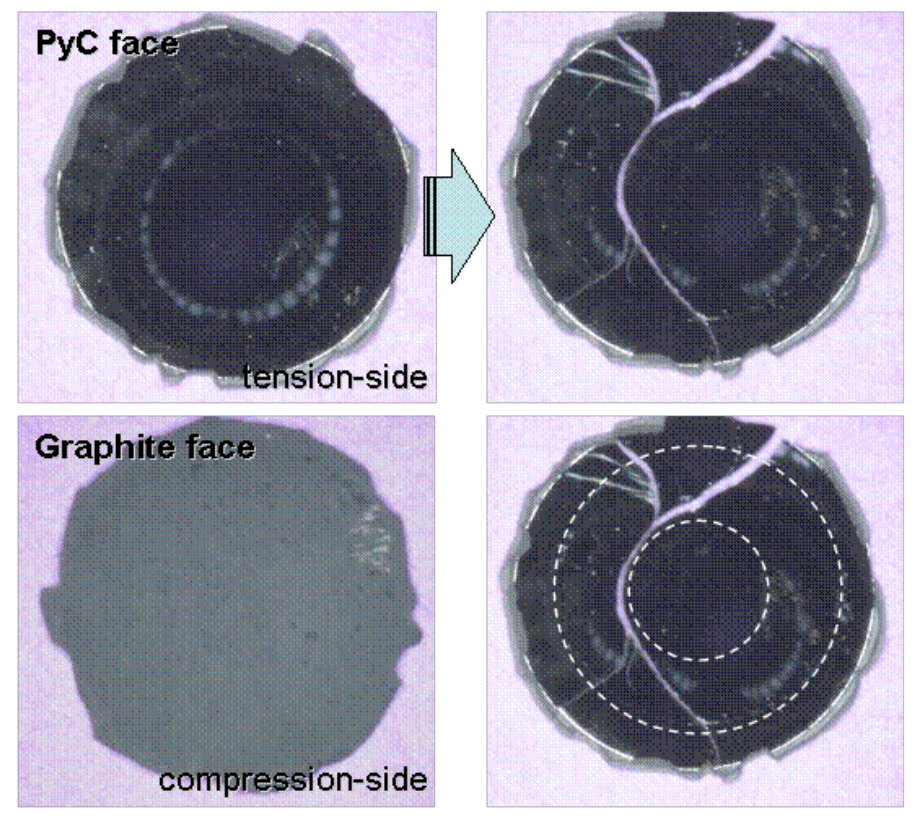

Remark:

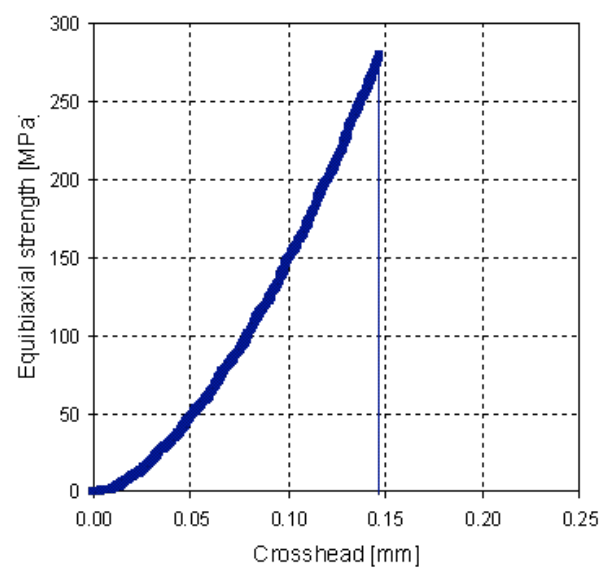


PyC080721_03

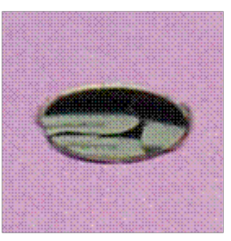

\begin{tabular}{|l|l|}
\hline Thickness [mm] & 0.1253 \\
\hline Peak Load [N] & 11.81 \\
\hline Flexural Stress [MPa] & 352.0 \\
\hline Likely Crack Origin & indicated by circle \\
\hline
\end{tabular}
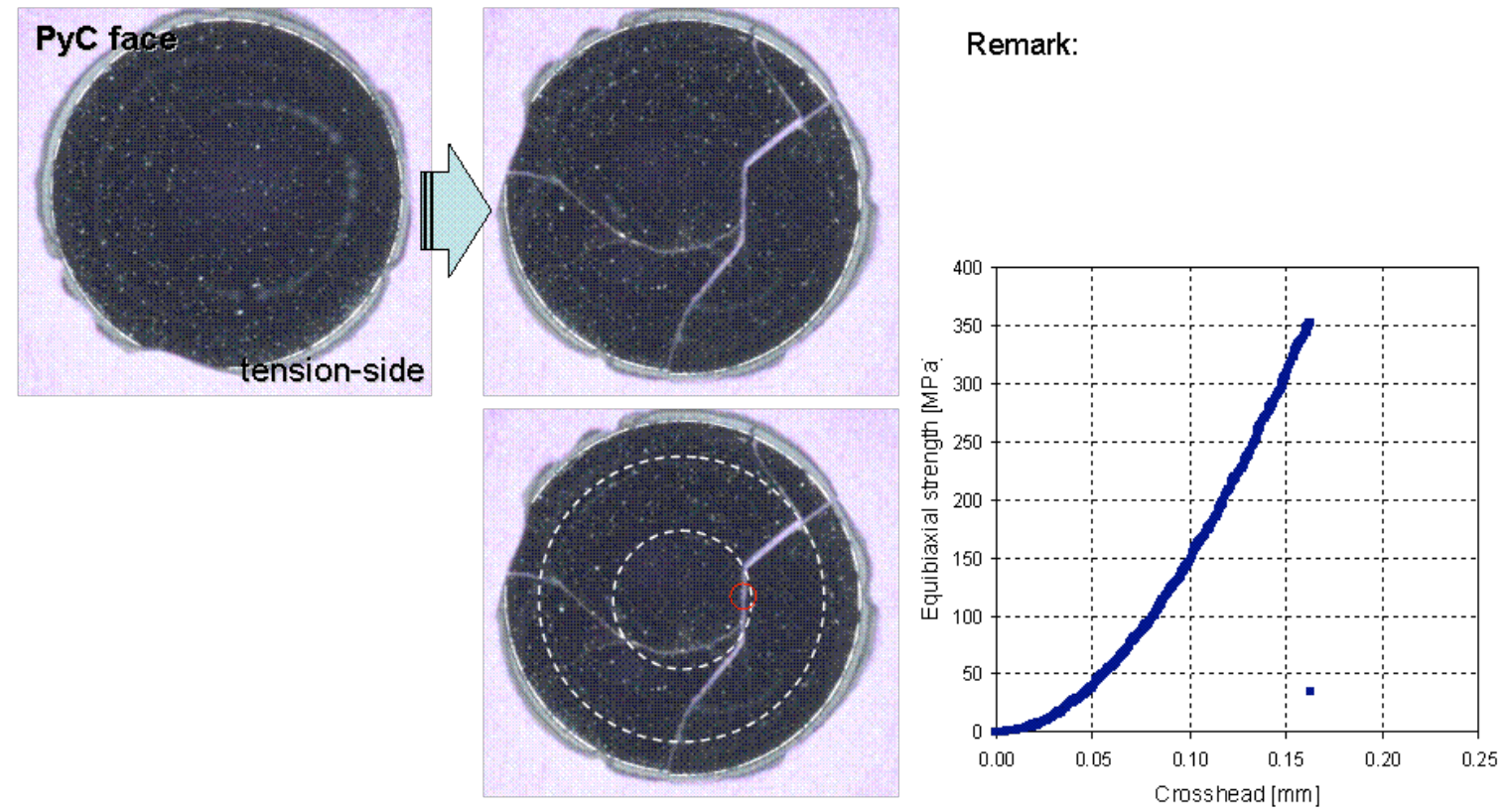
PyC080721_04

\begin{tabular}{|l|l|}
\hline Thickness [mm] & 0.1087 \\
\hline Peak Load [N] & 14.65 \\
\hline Flexural Stress [MPa] & 580.9 \\
\hline Likely Crack Origin & under loading ring \\
\hline
\end{tabular}

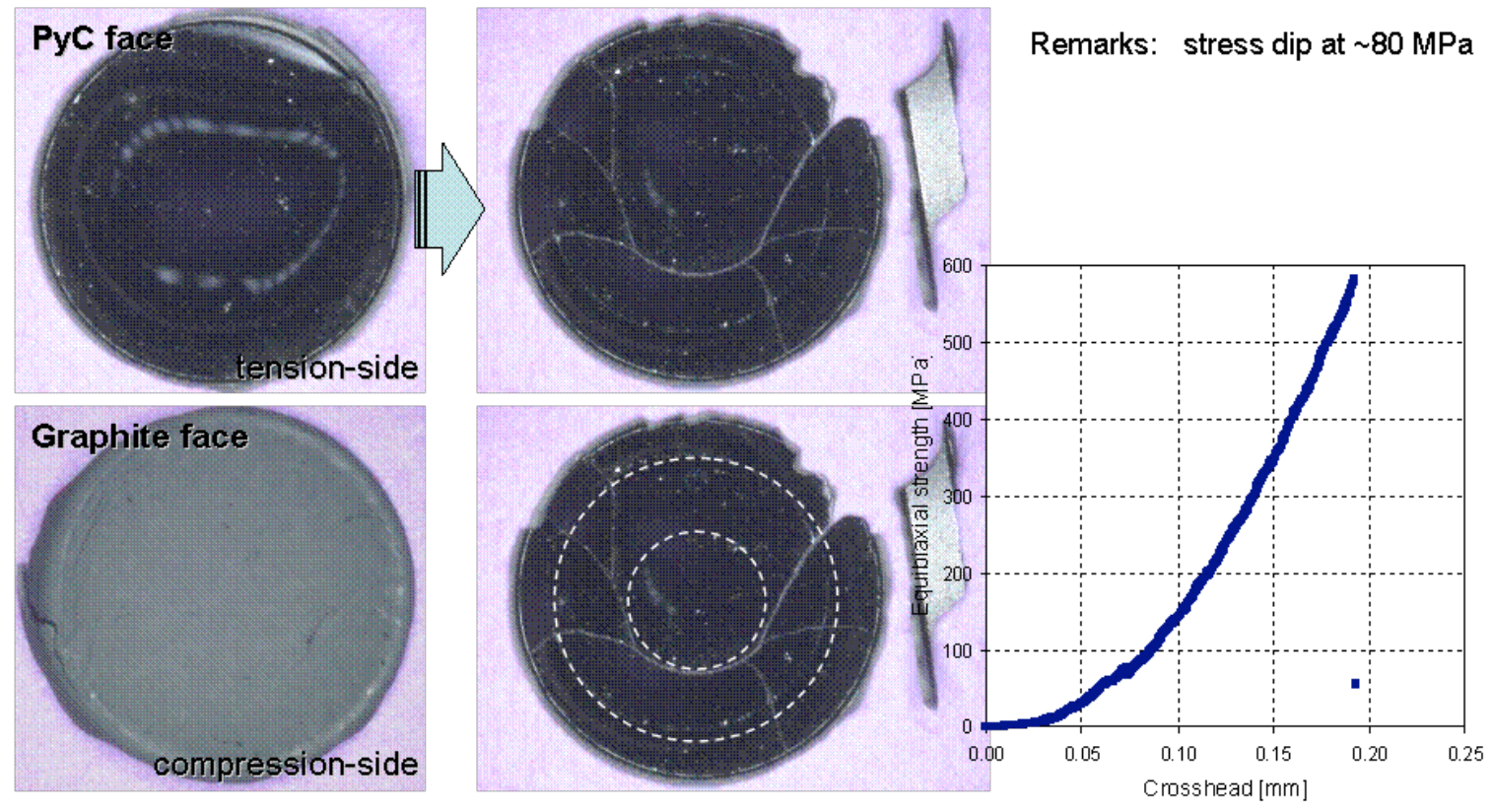


PyC080721_05

\begin{tabular}{|l|l|l|}
\hline Thickness [mm] & 0.1273 \\
\hline Peak Load [N] & 16.10 \\
\hline Flexural Stress [MPa] & 464.9 \\
\hline Likely Crack Origin & under loading ring \\
\hline
\end{tabular}

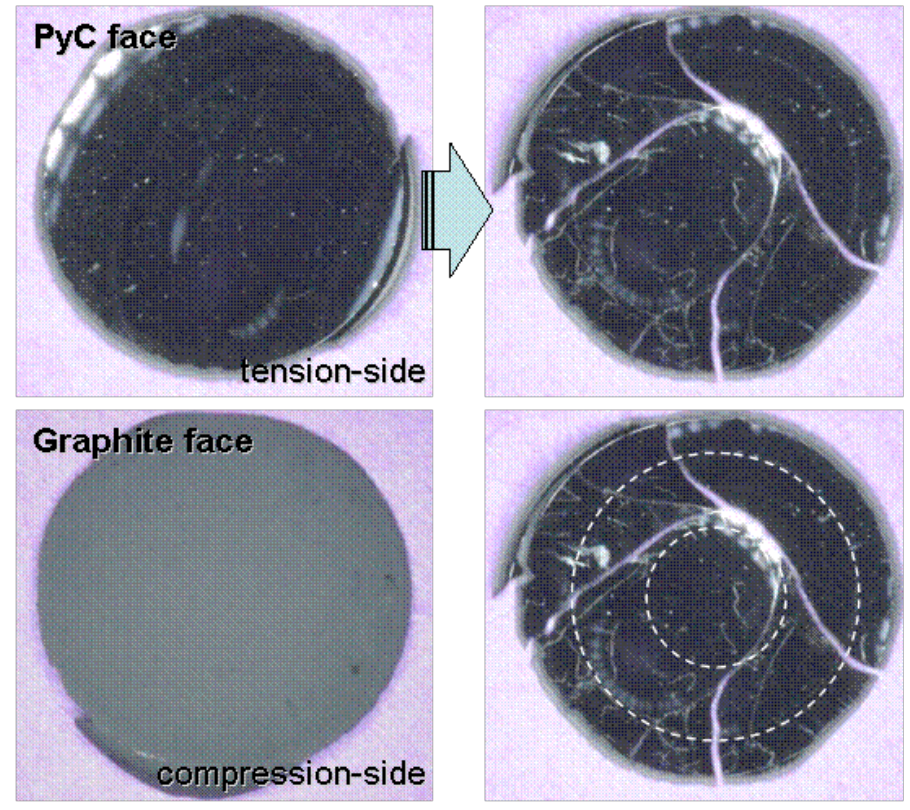

Remark: stress dip at $\sim 60 \mathrm{MPa}$

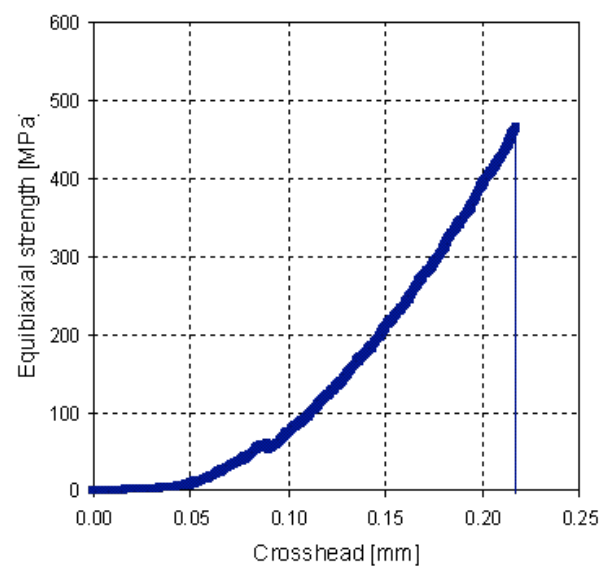




\section{PyC080721_06}

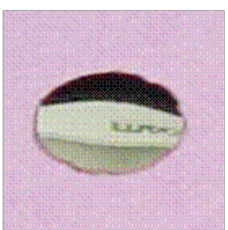

\begin{tabular}{|l|l|}
\hline Thickness [mm] & 0.1117 \\
\hline Peak Load [N] & 19.55 \\
\hline Flexural Stress [MPa] & 734.1 \\
\hline Likely Crack Origin & under loading ring \\
\hline
\end{tabular}
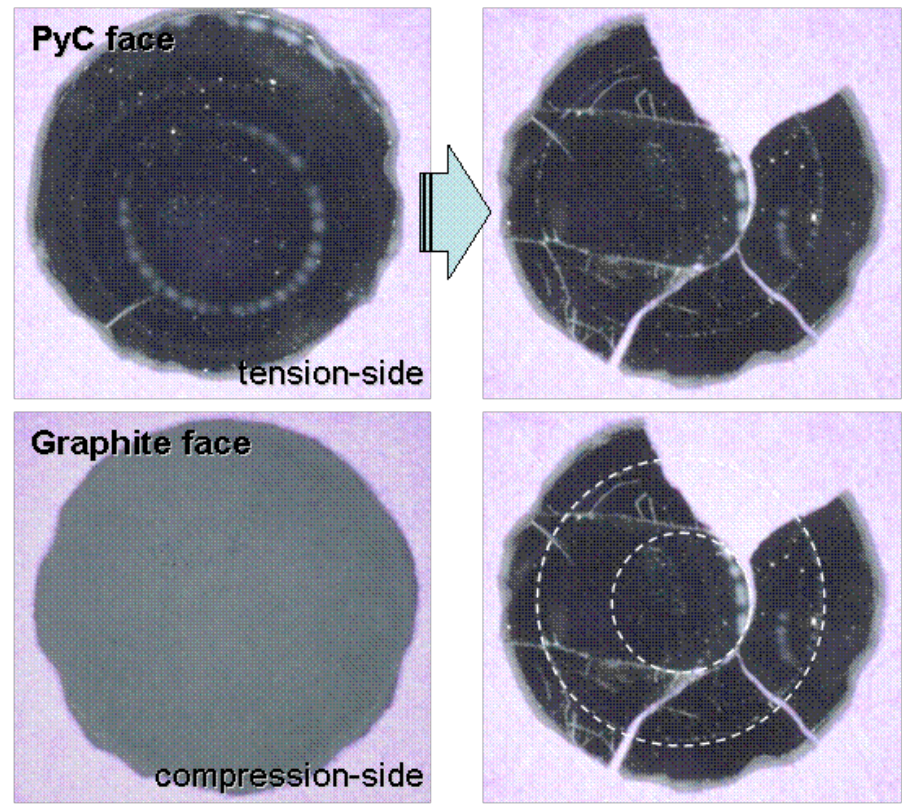

\section{Remarks: bad alignment? highest strength}

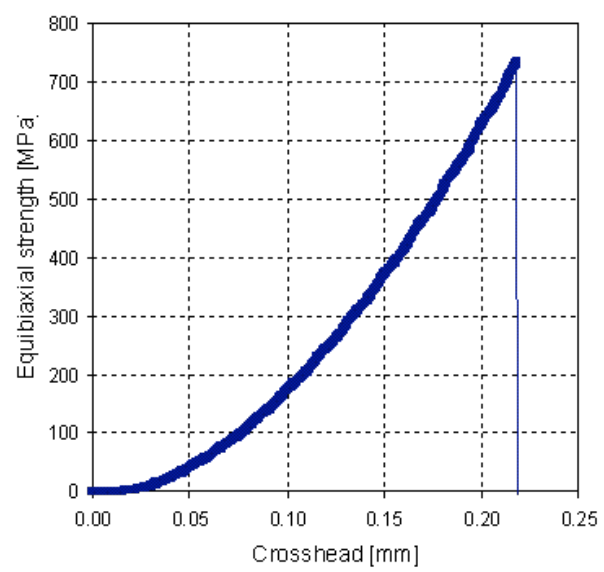


PyC080721_07

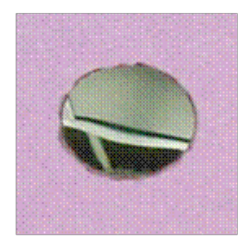

\begin{tabular}{|l|l|}
\hline Thickness [mm] & 0.1107 \\
\hline Peak Load [N] & 15.18 \\
\hline Flexural Stress [MPa] & 580.3 \\
\hline Likely Crack Origin & under loading ring \\
\hline
\end{tabular}
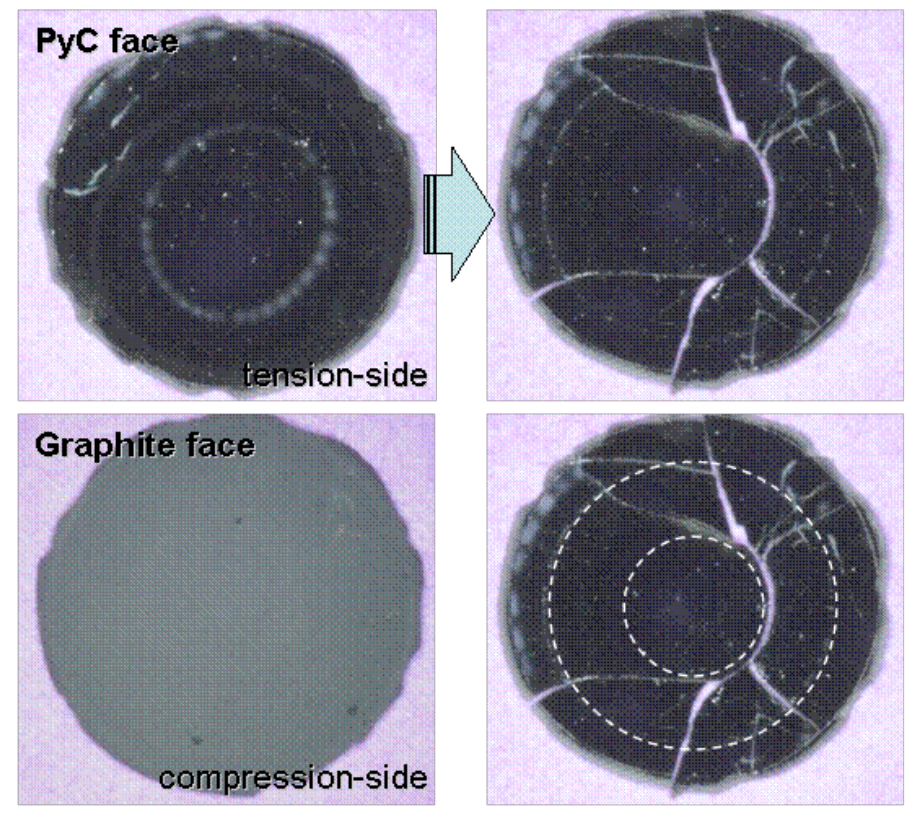

Remark:

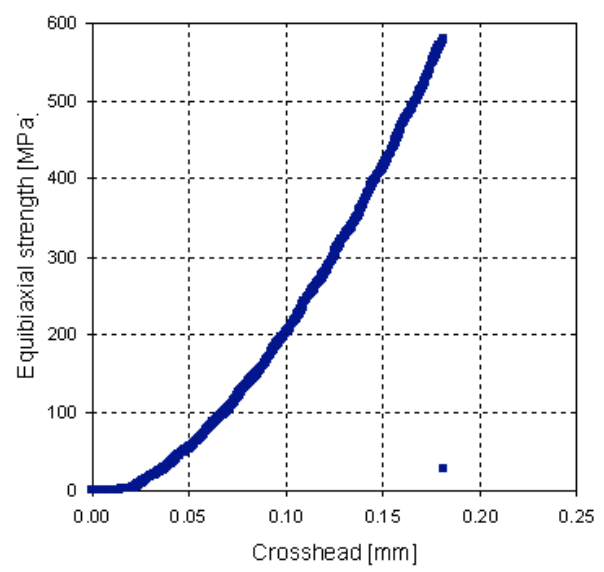




\section{Appendix B}

This Appendix contains a copy of Reference 2

J. H. Miller, K. M. Cooley, and B. C. Jolly, "Coating R\&D in Support of PyC Strength Measurement: FY08 Progress Report," Oak Ridge National Laboratory, September 2008, Oak Ridge, TN. 


\title{
Coating R\&D in Support of PyC Strength Measurement: FY08 Progress Report
}

\author{
J. H. Miller, K. M. Cooley, and B. C. Jolly
}

September 20, 2008

\section{Introduction}

The purpose of the coating activities for FY2008 was to begin to develop methods for producing representative pyro-carbon samples for strength measurements. Preliminary coating experiments related to the PyC strength determination effort have been conducted. Methods for producing representative carbon coating samples that are approximately $6 \mathrm{~mm}$ in diameter for strength measurements are being developed. To produce the samples, several $6 \mathrm{~mm}$ diameter disk substrates (up to 20 disks) are included with a batch of surrogate particles $\left(54 \mathrm{~g}\right.$ of $\left.500 \mu \mathrm{m} \mathrm{ZrO}_{2}\right)$, and are coated with a thin buffer coating $(\sim 25 \mu \mathrm{m})$ and a thick inner pyro-carbon (IPyC) coating $(\sim 100 \mu \mathrm{m}$ target thickness) using AGR-1 baseline coating conditions. It was determined in the initial experiments that a buffer layer was necessary to facilitate reliable debonding of the carbon disk from the sapphire substrate.

\section{$\underline{\text { Substrate selection }}$}

Graphite, alumina, and sapphire disks have been tested in an effort to determine which offers the best potential for coating removal without damage to the thin coating sample. A polished sapphire disk approximately $6 \mathrm{~mm}$ in diameter and $2 \mathrm{~mm}$ thick provided for the most reliable release of the carbon coating layer. Early experiments used an alumina ring press-fit around the circumference of the sapphire disk prior to coating in an attempt to encourage controlled fracture of the coating around the circumference of the sapphire substrate. A photograph of the sapphire disk and the alumina ring are shown in Figure 1. A photograph of a pyro-carbon disk produced using the sapphire disk/alumina ring assembly is shown in Figure 2. Both the buffer layer and the IPyC layer are visible in the picture.

The uneven edges produced when using the alumina ring as a crack control fixture were deemed unacceptable due to the inability to prevent crack propagation from the outside cylindrical surface "around the corner" and onto the flat disk surface of the carbon sample (Figure 2). The presence of a cylindrical edge (or corner) on the carbon coating sample can be accounted for computationally in the strength measurement technique, but in order to account for this "corner," it needs to be continuous all the way around the circumference of the sample and preferably of consistent height. With the edge/corner condition in mind, additional coating removal techniques are being developed.

\section{Pyro-carbon removal techniques}

The two coating removal techniques that show the most promise are circumferential cracking and turning. Laser cutting is also being considered, but its feasibility has not yet been established. Circumferential cracking involves manually cracking the coating around the circumference (outside cylindrical surface) of the coated sapphire disk using tweezers. This technique is shown schematically in Figure 3. The process of repeatedly cracking the coating under compression applied by the tweezers blades around the 
circumference of the coated disk is tedious and takes significant patience and dexterity. A cross sectional photograph of a pyro-carbon disk removed from the sapphire substrate by circumferential cracking is presented in Figure 4. The figure demonstrates the level of unevenness along the edge of the carbon disk. As discussed above, this unevenness, although not preferred, is acceptable as long as the corner of the sample stays intact.

The use of a lathe to remove a band of carbon coating from the cylindrical surface of the coated disk, termed the turning technique, is shown schematically in Figure 5. In turning, the coated sample is glued to a small rod on one side and supported on the other side by a soft elastomeric rod that is pressed against the surface of the sample. A small cutting tool is used to remove a band of the carbon coating on the cylindrical surface of the coated sample. After turning, the sample is removed from the lathe and the carbon disk is carefully removed from the sapphire substrate. A cross sectional photograph of a pyrocarbon disk produced by turning is shown in Figure 6. The photograph demonstrates the consistent edge/corner that results from the turning technique.

The turning technique produces samples with consistent edges, but it is tedious and time consuming. Also, due to having to glue the sample on one side for holding purposes, the turning process only yields one carbon disk sample per coated substrate. The circumferential cracking technique yields two. At present, neither coating removal process is clearly superior.

Pyro-carbon sample bowing

Another characteristic of the carbon disks produced by coating sapphire substrates is the bowing or curvature present in the disks. This bowing is evident in the cross sectional pictures shown in Figures 4 and 6 . This bowing is caused by residual thermal stresses induced by the coefficient of thermal expansion (CTE) mismatch between the carbon coating and the sapphire disk. The coating is applied at elevated temperature $\left(\sim 1265^{\circ} \mathrm{C}\right)$, and the CTE mismatch on cooling induces the thermal stresses that cause the bowing of the carbon disk and facilitate the debonding of the carbon coating from the sapphire substrate. The bowing presents added complexity to the strength measurement since it has to be accounted for, but the CTE mismatch that is responsible for the bowing is necessary for sample production.

A surface profile plot of a typical carbon disk, after removal from the substrate, is presented in Figure 7. A cross sectional photograph of a carbon sample is also shown in the figure. The profile plot shows a maximum height at the apex of the curvature of approximately $300 \mu \mathrm{m}$, but due to the method of measurement (as shown by the red lines drawn on the cross sectional photograph), this height also includes the thickness of the carbon sample $(\sim 100 \mu \mathrm{m})$. Therefore, the magnitude of the bowing exhibited in these samples is on the order of $200 \mu \mathrm{m}$.

\section{Conclusions}

As state above, the purpose of the coating activities for FY2008 was to begin to develop methods for producing representative pyro-carbon samples for strength measurements. As presented in this report, significant progress has been made on sample production. 
The most challenging technical issue related to sample production encountered thus far is the consistent removal of the carbon coating from the substrate onto which it was applied. Circumferential cracking and turning are both tedious and time consuming, but both appear to be feasible methods for carbon coating removal. The viability of laser cutting is yet to be determined. Planned future work involves down selecting and perfecting the carbon coating removal methods, and then producing carbon samples under a variety of conditions (with a variety of properties) so that the processing-properties relationships for pyro-carbon particle coatings can be determined. 


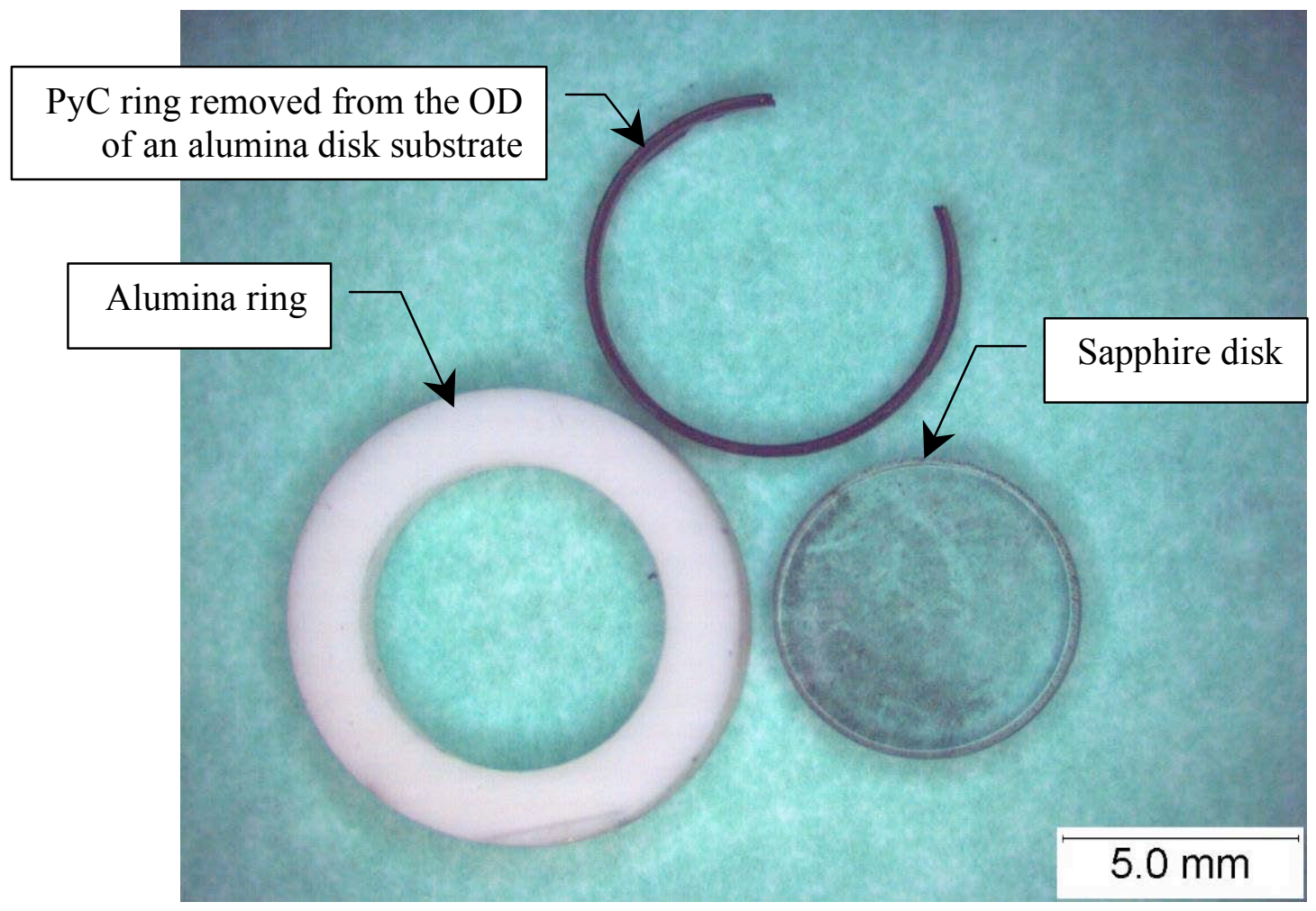

Figure 1. Photograph of the sapphire disk and alumina ring used in PyC strength coating sample production.

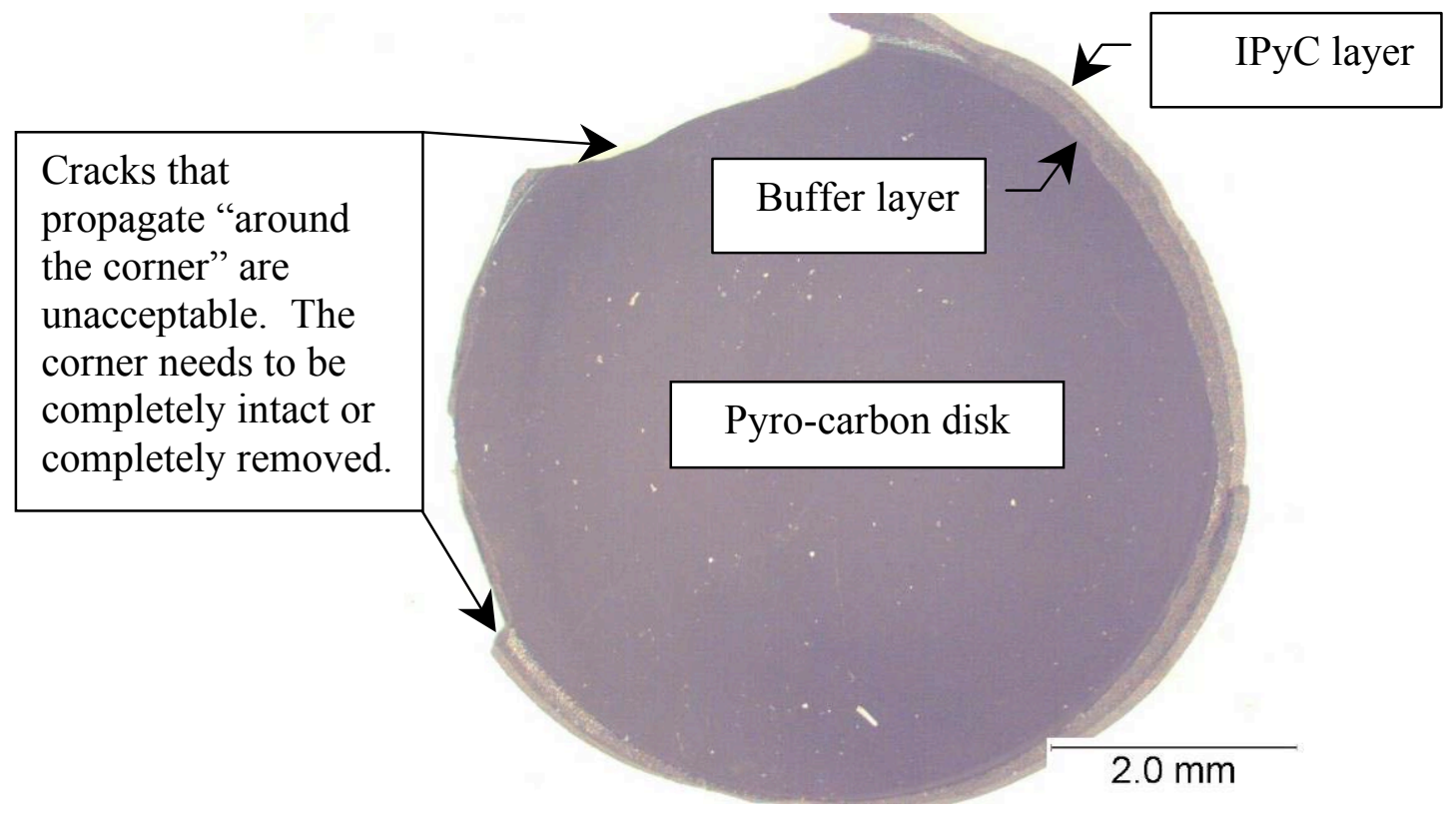

Figure 2. Photograph of a pyro-carbon disk sample after it has been removed from the sapphire disk/alumina ring assembly. 


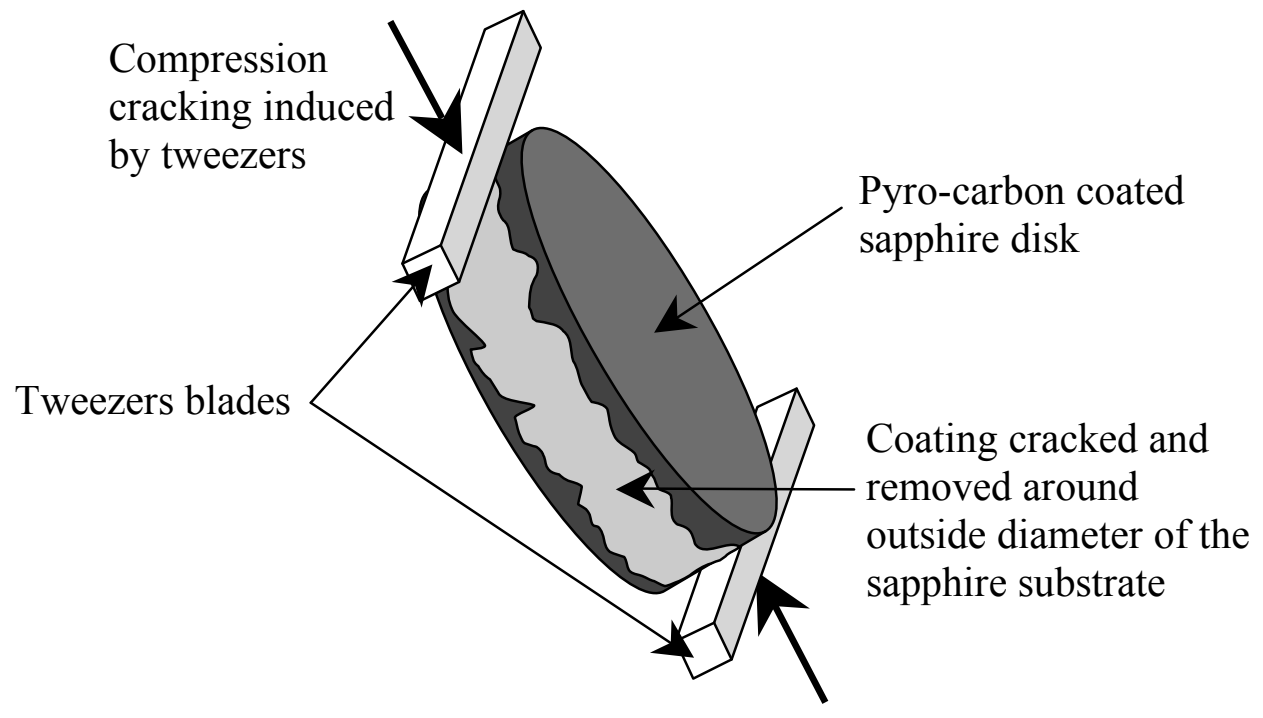

Figure 3. Schematic representation of the manual circumferential cracking technique for removing carbon disk samples from coated sapphire substrates.

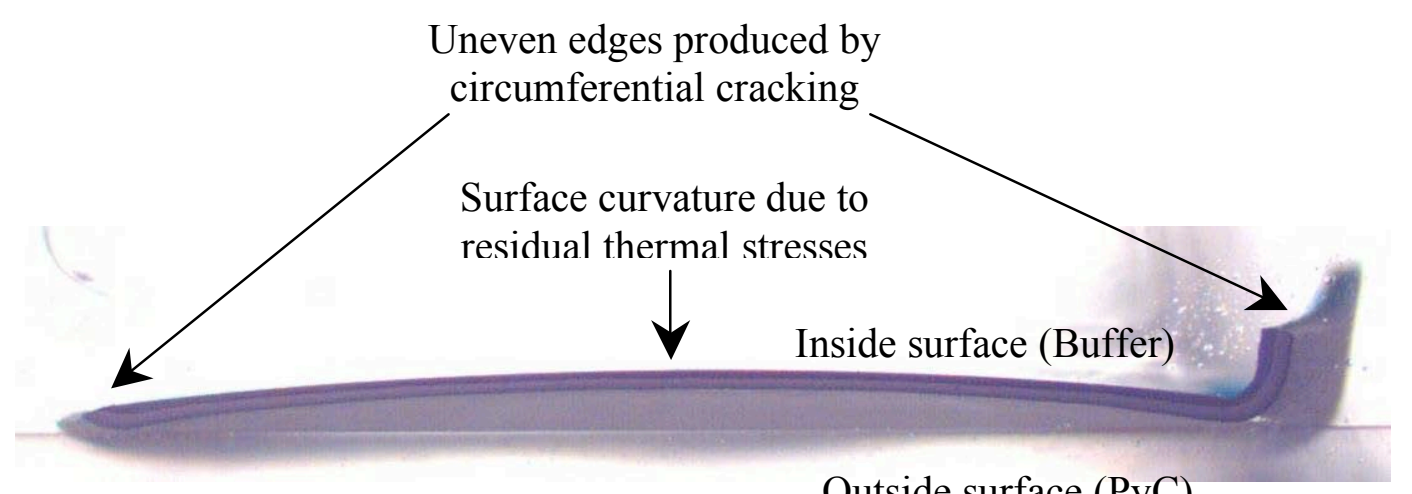

Outside surface $(\mathrm{PyC})$

Figure 4. Cross section photograph of a $6 \mathrm{~mm}$ diameter pyro-carbon removed from the sapphire substrate by circumferential cracking. 


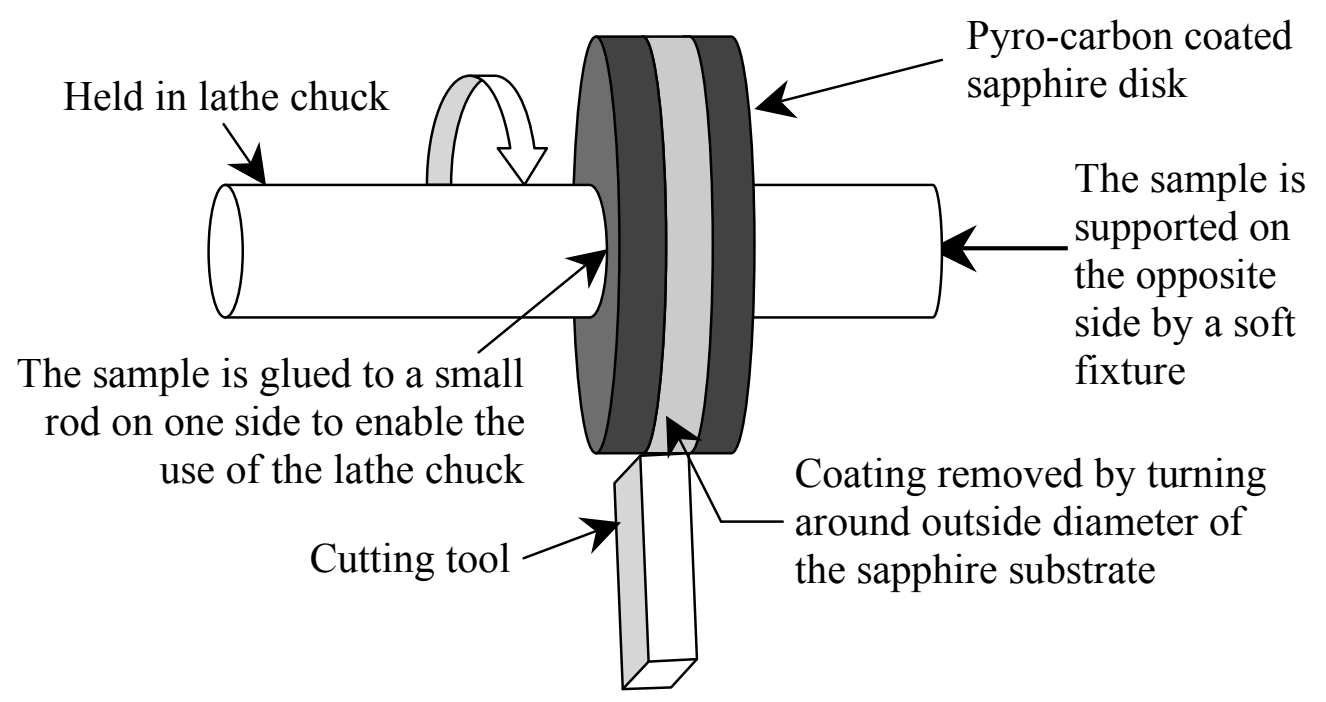

Figure 5. Schematic representation of the turning technique for removing carbon disk samples from coated sapphire substrates.

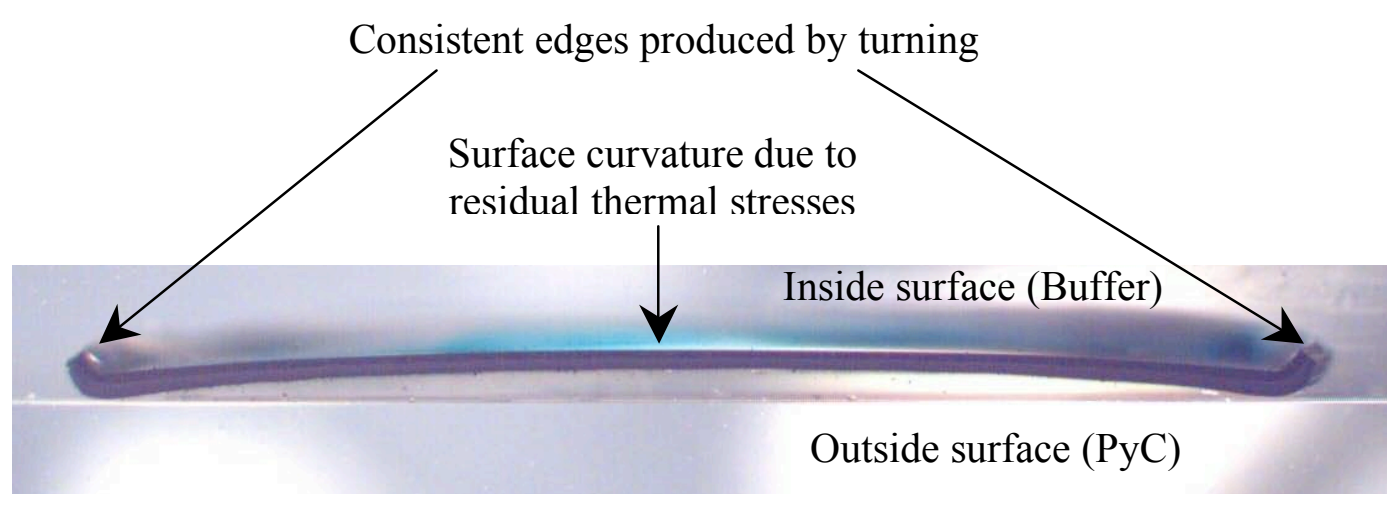

Figure 6. Cross section photograph of a $6 \mathrm{~mm}$ diameter pyro-carbon disk removed from the sapphire substrate by turning. 


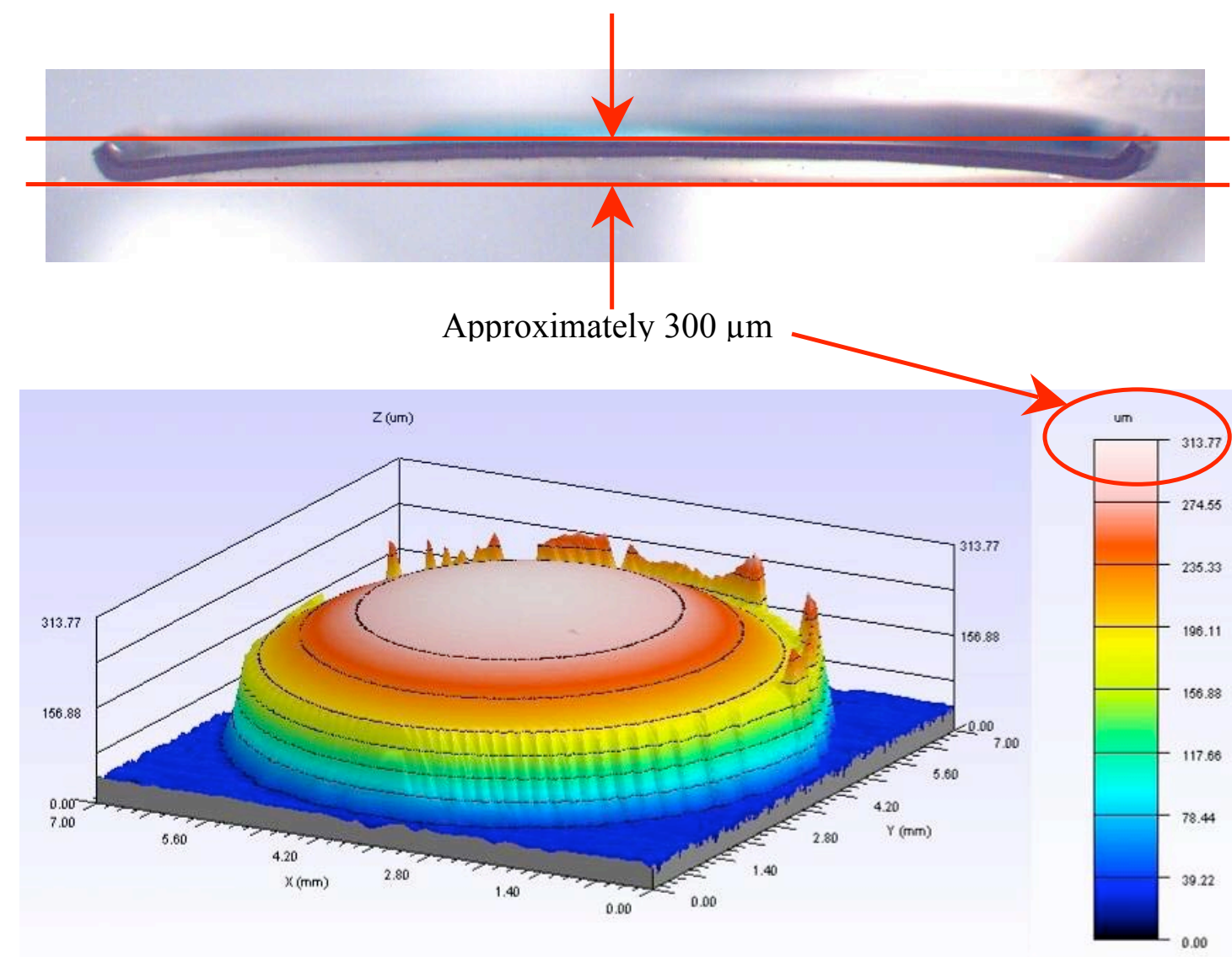

Figure 7. Surface profilometer measurements of a pyro-carbon disk removed from the sapphire substrate by turning showing the magnitude of the disk curvature. 